\title{
Archipel
}

A RCHIPEL Études interdisciplinaires sur le monde insulindien

$98 \mid 2019$

Varia

\section{The International Intensive Courses in Old Javanese (2014-2019)}

Andrea Acri, Arlo Griffiths, Aditia Gunawan et Agung Kriswanto

\section{(2) OpenEdition}

\section{Journals}

Édition électronique

URL : http://journals.openedition.org/archipel/1271

DOI : 10.4000/archipel.1271

ISSN : 2104-3655

Éditeur

Association Archipel

\section{Édition imprimée}

Date de publication : 3 décembre 2019

ISBN : 978-2-910513-82-5

ISSN : 0044-8613

\section{Référence électronique}

Andrea Acri, Arlo Griffiths, Aditia Gunawan et Agung Kriswanto, «The International Intensive Courses in Old Javanese (2014-2019) », Archipel [En ligne], 98 | 2019, mis en ligne le 11 décembre 2019, consulté le 16 mars 2021. URL : http://journals.openedition.org/archipel/1271 ; DOI : https://doi.org/ 10.4000/archipel.1271 


\section{The International Intensive Courses in Old Javanese (2014-2019)}

Old Javanese is the foremost classical language of Indonesia. Competence in this language provides access to a rich Indianized literary tradition and a wide epigraphic corpus covering the period from 800 to $1500 \mathrm{CE}$. But it is not regularly taught in any Western university, and no solid conditions for its study exist even in Indonesia. Given this state of affairs, the École française d'Extrême-Orient (EFEO) and the National Library of Indonesia (Perpusnas) launched a collaboration for the first time in 2014 to organize an "International Intensive Course in Old Javanese," in the framework of cooperation between these two institutions formalized in 2013 through a memorandum of understanding.

After the first course was held from 13 to 28 June 2014, a second one followed from July 31 to August 15, 2015, and a third one from 14 through 25 July 2017. These three events were organized at the Integrated Outdoor Campus of Universitas Surabaya in Trawas, Mojokerto, East Java. The fourth edition was then organized at Cangkringan Villa \& Spa, in Sleman, D.I. Yogyakarta, 15 through 29 July 2018, as was the fifth, from 21 July through 3 August 2019.

This summer school has brought together for two-week periods substantial groups of people wishing to learn or deepen their knowledge of Old Javanese. The majority of the students were Indonesian: staff of Perpusnas, researchers in philology and archaeology, teachers, university researchers, and students in $\mathrm{MA}$ or $\mathrm{PhD}$ programs. As for the foreigners, the events were attended each time by younger or more advanced scholars of various nationalities, among whom participants from France, the Netherlands, India, Cambodia, 
Thailand and several North Americans. The basic approach was to provide a week of intensive training in grammar, followed by a week of daily readings of representative genres of text - the lingua franca being English, but Indonesian explanations being provided when necessary. From the second intensive course, held in 2015, onward, we have also welcomed alumni of a previous course to continue on advanced level, reading more difficult texts, often those being the focus of current research. At the fifth and most recent course, we experimented with a parallel program for beginners taught in Indonesian. While at previous events, the number of participants had been capped at 22 (with 3 or 4 teachers), the fifth intensive course expanded in size, with a total number of 37 participants (with 6 teachers).

Willem van der Molen (KITLV, Leiden, the Netherlands) was lead teacher at the first four events, being assisted by Dwi Puspitorini (Universitas Indonesia, Depok) and Arlo Griffiths (EFEO). In 2015, Andrea Acri (then of ISEASYusof Ishak Institute, Singapore, and Nalanda University, India) joined the team of teachers. The same team has remained involved at subsequent events, though in 2019 their places were partly filled by Thomas Hunter (University of British Columbia, Vancouver, Canada), Yosephin Apriastuti Rahayu (Universitas Gadjah Mada, Yogyakarta), Agung Kriswanto (National Library of Indonesia) and Zakariya Pamuji Aminullah (Universitas Gadjah Mada, Yogyakarta). For the French side, Arlo Griffiths has led the organization of the programs, from 2017 onwards in collaboration with Andrea Acri (since 2017 at EPHE). On the Indonesian side, organization was coordinated at Perpusnas by Aditia Gunawan and Agung Kriswanto.

With some slight variations, the formula has been to offer the course free of cost for participants, except for their travel expenses, while some travel fellowships have been offered to graduate students coming in from outside of Indonesia. The organization has been able to cover all other expenses through generous contributions made by Perpusnas, which has always signed for about two-thirds of the total budget. The EFEO has been the second contributor, partly with its own funds and partly through the French Embassy in Indonesia and from PSL University, among others by its scheme of Soutien aux Projets Innovants de Formation, from which the EFEO has for the past years been able to finance teaching activities in the project called 'Ancient Texts, Languages and Archaeologies of South and South-East Asia' (ATLAS). Other contributions have been made by the Centre Asie du Sud-Est (UMR 8170, EHESS-CNRS, Paris) and by the KITLV (Leiden, the Netherlands).

The first three editions of the summer school were held in a particularly suitable place for intensive study, in the province of East Java, surrounded by several impressive archaeological sites contemporary with the Old Javanese texts studied. Excursions to visit such archaeological remains have been part of the programs during most years, also after the shift to D.I. Yogyakarta. In all, participants received at each event about 70 hours of intensive 
coursework, well beyond the equivalent of two semesters of regular classes at most universities. Advanced researchers worked with young students, and foreigners with Indonesians. Representatives from disciplines as diverse as Sanskrit philology, Indonesian archaeology, linguistics, and the history of Burma interacted during the schools.

The positive impact on Franco-Indonesian exchange in this field has been immediate: an Indonesian participant of 2014 completed his M2 at INALCO in 2016, and has recently returned to Paris for his doctorate at the EPHE; an Indonesian participant for the year 2015 completed his MA at the EPHE in 2019, and has returned to teach Old Javanese at UGM in Yogyakarta. Other Indonesian students are now preparing to follow in their footsteps, while French students are profiting for research and fieldwork from exchange with junior and senior Indonesian scholars.

All parties involved judge this initiative to be sufficiently successful for it to be continued in coming years. In organizing future editions, our aim will be to keep fostering an approach to the Javanese past from the perspective of centuries of cultural contact between South and Southeast Asia, specifically the interplay between the "cosmopolitan" Sanskrit and the "cosmopolitan vernacular" Old Javanese languages and their literatures; to encourage a multidisciplinary perspective (e.g., by exposing the participants not only to textual studies but also to the archaeology, art history, and religious history of the region); and to provide a forum for the academic interaction between Indonesian and foreign students, from West to East and East to West.

\author{
ANDREA ACRI ${ }^{1}$, ARLO GRIFFITHS ${ }^{2}$, \\ ADITIA GUNAWAN AND AGUNG KRISWANTO ${ }^{3}$
}

1. EPHE.

2. EFEO.

3. Perpustakan Nasional RI. 


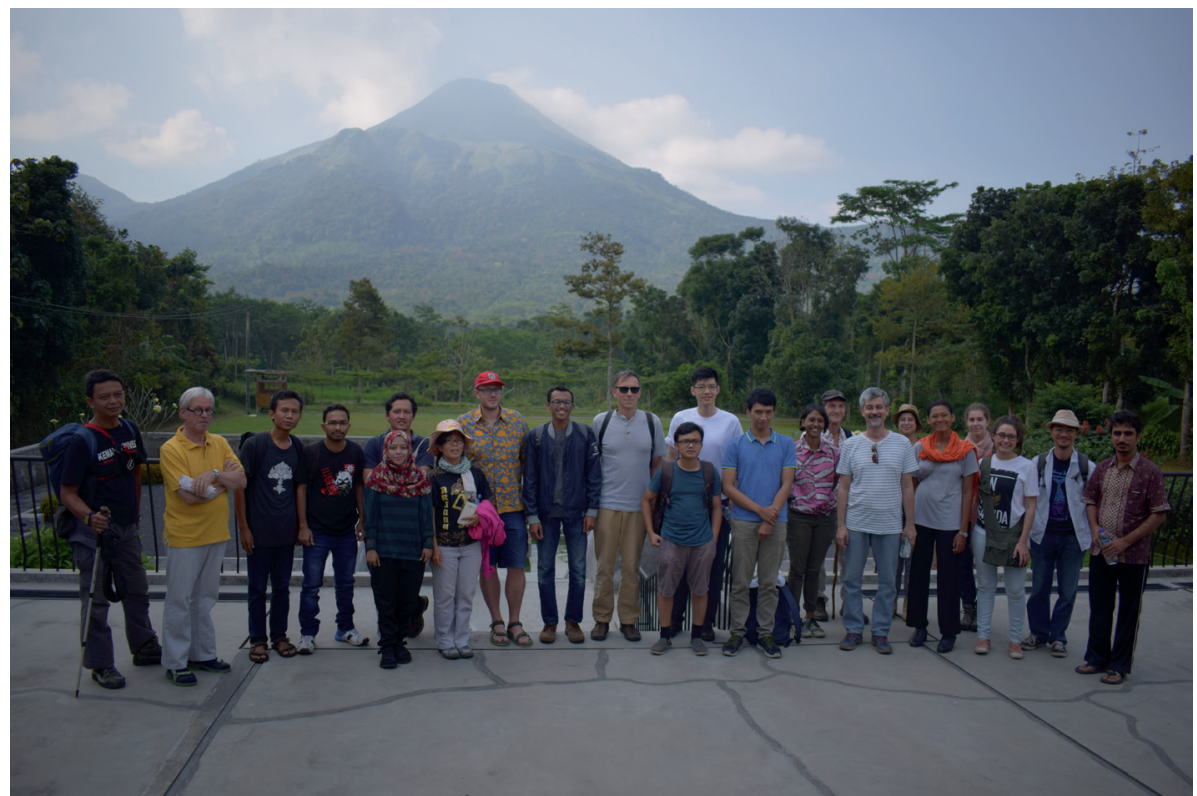

Fig. 1 - Most of the participants of the 3rd International Intensive Course in Old Javanese pose with Mount Penanggungan in the background, Trawas, 2017.

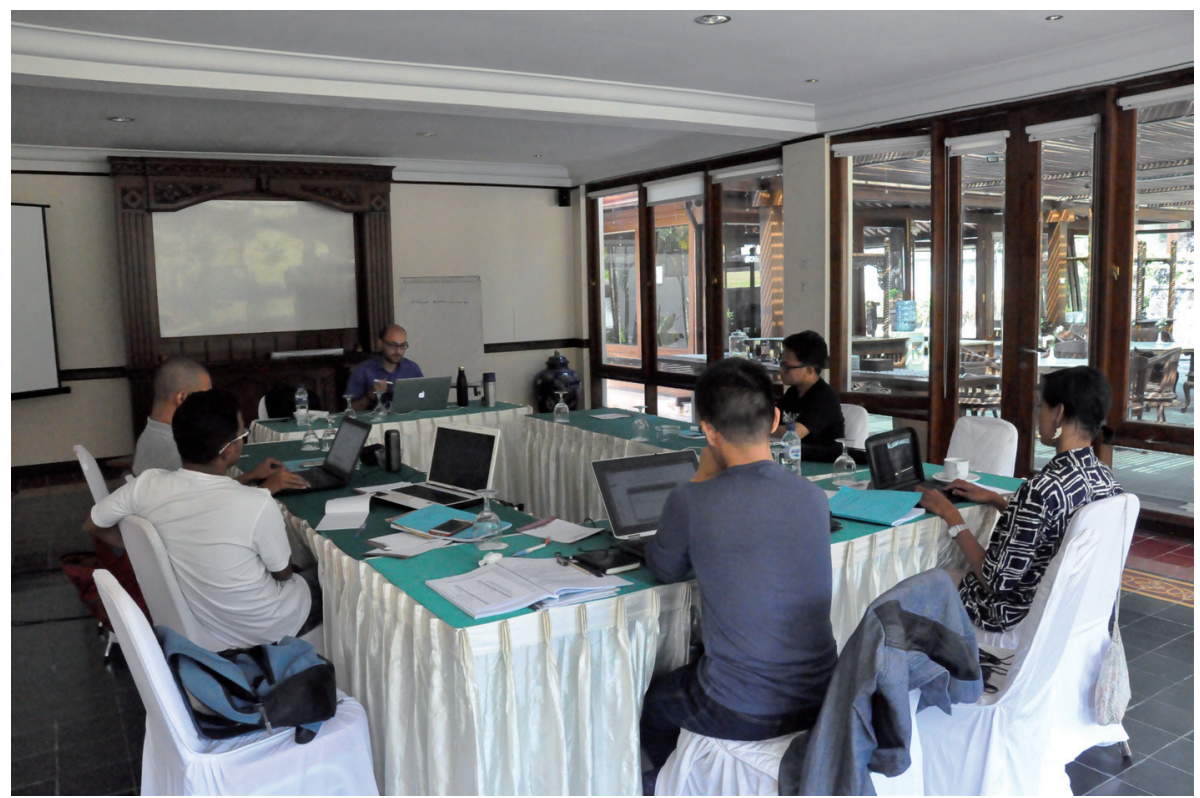

Fig. 2 - Andrea Acri leads a session of the advanced class during the 4th International Intensive Course in Old Javanese, Cangkringan, 2018. 